\title{
A GIS-based Waste Water Monitoring System Using LoRa Technology
}

\author{
Yudi E. Windarto \\ Department of Computer Engineering \\ Diponegoro University \\ Semarang, Indonesia \\ yudi@live.undip.ac.id
}

\author{
Agung B. Prasetijo \\ Department of Computer Engineering \\ Diponegoro University \\ Semarang, Indonesia \\ agungprasetijo@ce.undip.ac.id
}

\author{
Galang F. Damara \\ Department of Computer Engineering \\ Diponegoro University \\ Semarang, Indonesia \\ gfdamara@student.ce.undip.ac.id
}

\begin{abstract}
Industrial waste is one of the causes of water pollution. Such waste requires periodic and continuous surveillance so that it can be followed up for specific treatments. This research develops LoRa (Long Range) technology for monitoring waste water based on geographic information system. Sensors used in this research are turbidity, $\mathrm{pH}$, and temperature sensors. The result of this research is a system capable of displaying and mapping the conditions of waste water under surveillance. Alerts are generated when the quality of waste water reaches a threshold value set to the owner of the factory. The accuracy of the turbidity sensor under test is $\mathbf{9 3 . 4 2} \%$.
\end{abstract}

Keywords—Water, System, LoRa, Technology, Monitoring

\section{INTRODUCTION}

Factory liquid waste contains synthetic materials that are difficult to dissolve in water and are very dangerous if the waste is delivered directly to the environment with the absence of sufficient processing [1]. Supervision of factory's liquid waste ruled by the local government enforces factories conduct laboratory tests for their waste water to measure its concentration of waste whether it has been in accordance with the applied regulations or not.

The advancement of computer and communication technology must be able to provide alternative ways in monitoring factory's liquid waste. One of them is by making a monitoring tool that can assess the quality of liquid waste. For example, wireless sensor network collaborates with Geographic Information System (GIS) for water quality monitoring in Bristol City [2].

In this paper, we develop a waste water monitoring application that uses LoRa (Long Range) technology. Sensors needed for waste water monitoring devices include temperature sensors, $\mathrm{pH}$ sensors, and turbidity sensors. LoRa technology is used to improve the quality of data transmission from monitoring tools to the server [3]. LoRa is one of the communication technologies that utilizes radio signals, which have advantages as follow: energy efficient, wide range as well as fast and safe data transmission [4]. Data taken from the sensor is represented in a way that the user can understand and use it easily. The Geographic Information System (GIS) is used in the system to show data according to its geographical location.

\section{LITERATURE REVIEW}

Internet of Things (IoT) is a topic that very popular today among practitioners and researchers. Although various definitions have been proposed in recent years, there is no uniform understanding of the IoT concept so far [5]. Internet of Things is based on an integrated system of various types of identification, sensing, networking, and computation processes [6]. The enabling technology becomes large-scale and additional services that personalize user interactions with various things. IOT can be used for various fields such as traffic, logistics, health, agriculture, smart city, long distance monitoring, and process automation. In this case, IoT holds great benefits for the private sector and the public sector [7].

Internet of Think (IoT) is the concept of an object that has the ability to transfer data through a network in the form of interaction between machines [8]. In the application of IoT many communication technologies between systems that can be used, one of which is LoRa (Long Range) [9]. LoRa is a modulation process using FM modulation [10]. The use of LoRa technology to be one of the best choices in IoT development is because LoRa is easy to build between machines that can be connected to the internet so the user can easily access such machines [11]. LoRa also provides features that support the development of smart city associated with the concept of IoT [12].

Data gathered from sensors can be collected by the sensors and outputted to the Geographic Information System (GIS)based tool. This GIS is a system developed to manage, analyze and display geographic information [13]. Geographic Information Systems offers a system that integrates spatial data with textual data in which it is a thorough description of the object and this eases users to disseminate relation to other objects in the space of the earth [14].

\section{MeTHODOLOGY}

\section{A. Hardware Design}

The hardware design employs temperature sensor, turbidity sensor, PH sensor, a microcontroller (Arduino Uno) and shell (Dragino), as well as Gateway LoRa. The hardware design is shown in Fig. 1. 


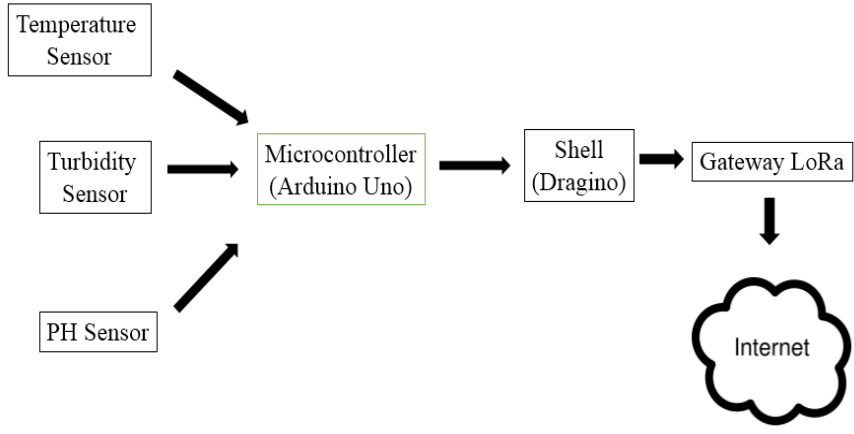

Fig. 1. Hardware Design

The function of each component is as follows:

1. Sensor temperature is used to measure the heat of waste water.

2. Turbidity sensor is to measure the waste water turbidity level.

3. $\mathrm{pH}$ sensor is to measure the level of acidity of waste water.

4. Microcontroller (Arduino Uno) is used to process sensor reading values and determine the waste water status.

5. Shell (Dragino) is to forward the data read from a microcontroller to the LoRa gateway.

6. The LoRa gateway is to provide channels for the monitoring tool in order to connect to the GIS-based monitoring server via the internet.

Fig. 2 shows the connection of microcontroller to the application server.

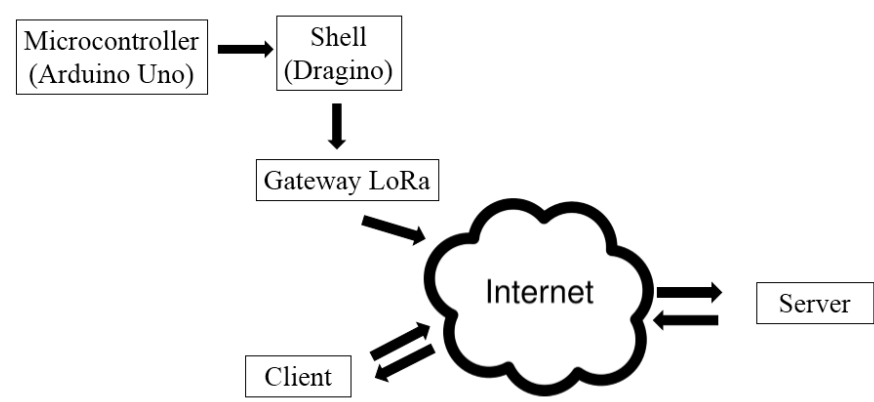

Fig. 2. LoRa to provide a gateway for the microcontroller to the server.

The reading of the Dragino for the sensor data will be forwarded and stored temporarily on the LoRa gateway before being forwarded to the server via the Internet. The data available on the server can be accessed by the clients through web browsers in which it is displayed at the GIS-based application at respective geographic areas.

\section{B. Software Design}

The software design is used to provide a clear step for creating the program that displays data from hardware. A system credential must be used. Username and password are required to enter the GIS-based system. Fig. 3 shows the flowchart of the system.

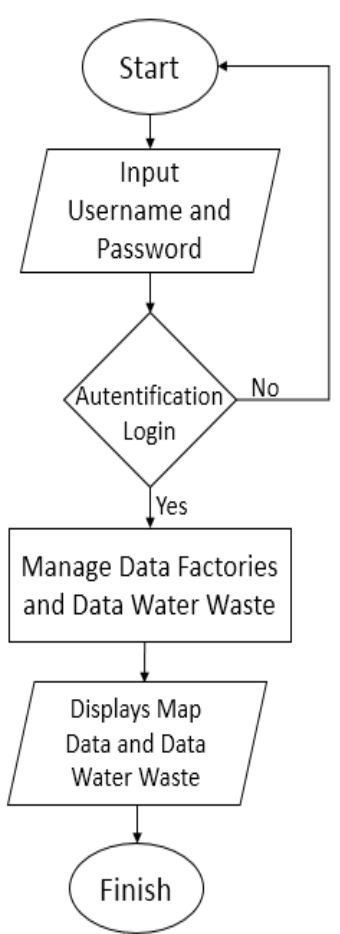

Fig. 3. Flowchart of the System

\section{RESULT}

The system has been created and tested, from the view of a Geographic Information System and the reading of monitoring instrument sensors.

\section{A. Geographic Information System}

Geographic Information System (GIS) can be accessed by users with the use of web browsers. The start page view of the system displays map and data showing factory position points as shown in Fig. 4.

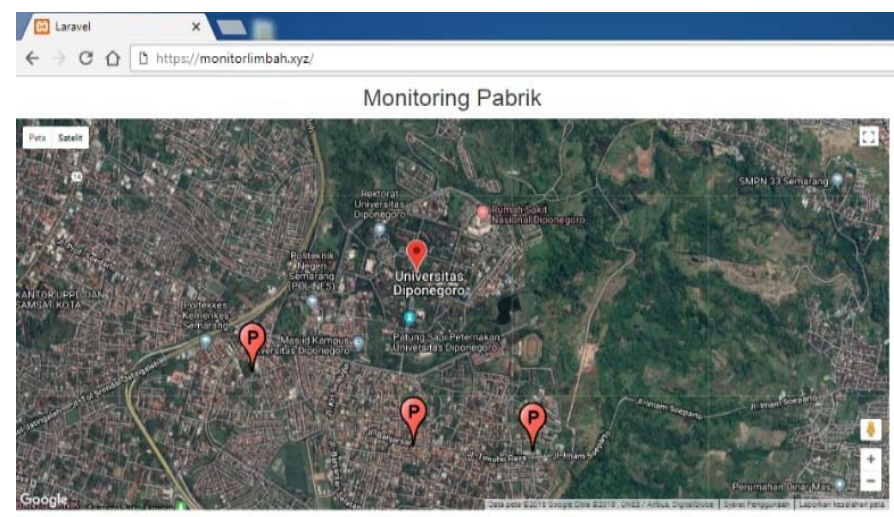

Fig. 4. GIS-based application showing factory positions.

This information system displays information about factories, as shown in Fig. 5. Information regarding to factories, their production water, and waste water can be managed remotely (dummy data can be seen in Fig. 5 - Fig. 7). 


\section{Manage Data Pabrik}

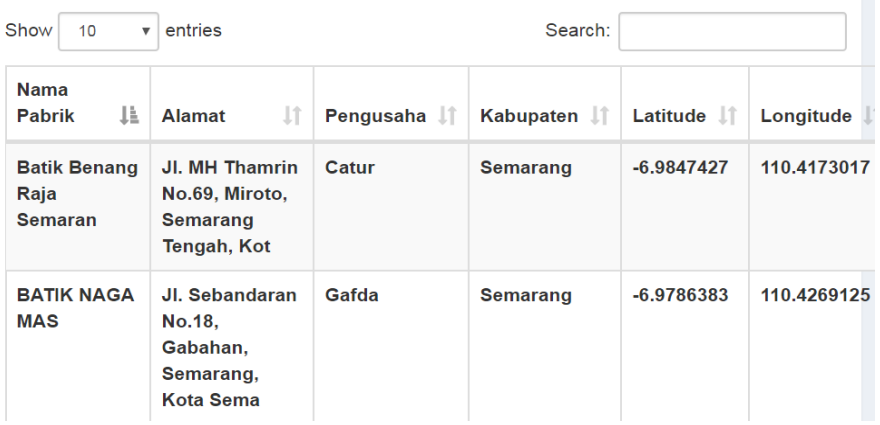

Fig. 5. Data of the Factories

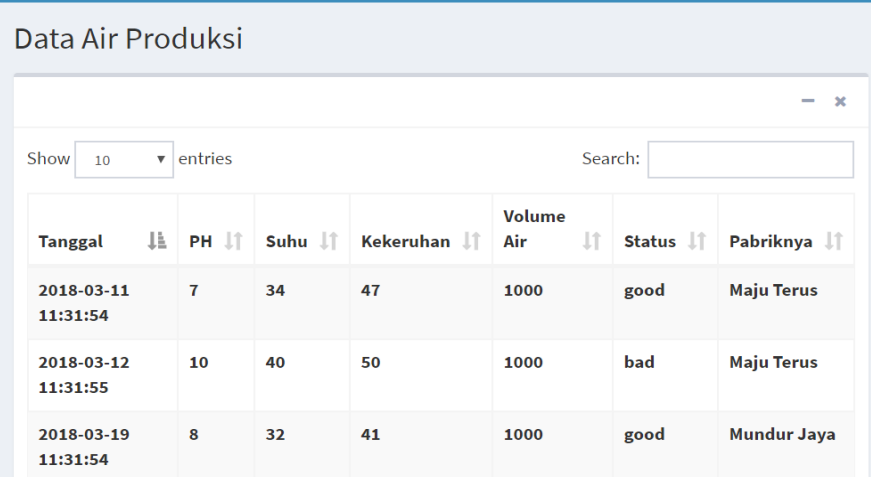

Fig. 6. Data Input

Data Air Limbah

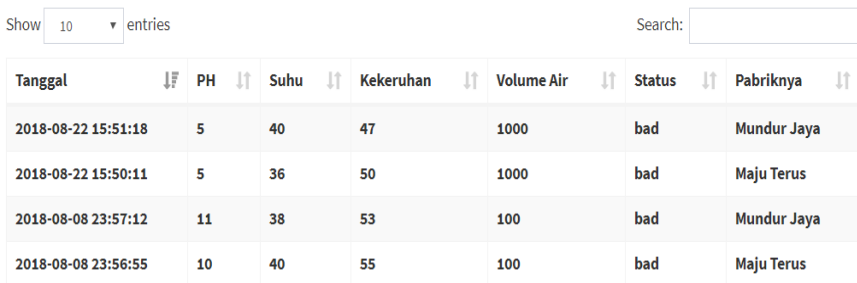

Fig. 7. Data of the Wastewater

\section{B. Temperature Sensor (DS18B20)}

Sensor DS18B20 is a sensor used to measure water temperature. Sensor testing is done by comparing the value of sensor output with a digital thermometer available in market. Testing is done five 5 times for every temperature set in Table 1. The accuracy of sensor measurements averaged $96.77 \%$.

Table 1 Temperature Sensor Test Results (DS18B20)

\begin{tabular}{|l|l|l|l|l|l|}
\hline Testing & $\begin{array}{l}\text { Comparati } \\
\text { ve } \\
\left({ }^{\circ} \mathbf{C}\right)\end{array}$ & $\begin{array}{l}\text { Tool } \\
\text { Temperature } \\
\text { Sensor }\left({ }^{\mathbf{O}} \mathbf{C}\right)\end{array}$ & Error & $\begin{array}{l}\text { Fault } \\
\text { Tolera } \\
\text { nce }\end{array}$ & $\begin{array}{l}\text { Accur } \\
\text { acy } \\
(\%)\end{array}$ \\
\hline 1 & 34 & 33 & 2.94 & 1 & 97.06 \\
\hline 2 & 33 & 31 & 6.06 & 2 & 93.94 \\
\hline 3 & 36 & 37 & 2.78 & 1 & 97.22 \\
\hline 4 & 49 & 50 & 2.04 & 1 & 97.96 \\
\hline 5 & 43 & 44 & 2.32 & 1 & 97.67 \\
\hline Average & & & 3.23 & 1.2 & 96.77 \\
\hline
\end{tabular}

\section{C. $\mathrm{pH}$ Sensor}

Sensor testing was performed by using a $\mathrm{pH}$ calibration powder diluted with water of $250 \mathrm{~mL}$. The solution used was a solution of $\mathrm{pH} 4.00, \mathrm{pH} 6.86$, and $\mathrm{pH} 9.18$. The $\mathrm{pH}$ value is taken 3 times for every experiment and the results are averaged. Table 2 shows the results of $\mathrm{pH}$ sensor testing.

Table 2 PH Sensor Testing

\begin{tabular}{|l|l|l|l|l|l|}
\hline Testing & $\begin{array}{l}\text { Calibrati } \\
\text { on Fluid }\end{array}$ & $\begin{array}{l}\mathbf{p H} \\
\text { Sensor }\end{array}$ & $\begin{array}{l}\text { Error } \\
\mathbf{( \% )}\end{array}$ & $\begin{array}{l}\text { Fault } \\
\text { Tolera } \\
\text { nce }\end{array}$ & $\begin{array}{l}\text { Accuracy } \\
\mathbf{( \% )}\end{array}$ \\
\hline Acid & 4 & 3.9 & 2.5 & 0.1 & 97.5 \\
\hline Neutral & 6.86 & 6.7 & 2.33 & 0.16 & 97.67 \\
\hline Base & 9.18 & 9.1 & 0.87 & 0.08 & 99.13 \\
\hline Average & & & 1.9 & 0.11 & 98.1 \\
\hline
\end{tabular}

Based on Table 2, the average accuracy of $\mathrm{pH}$ sensor measurement reached $98.1 \%$ of the calibration solution.

\section{Turbidity Sensor (SEN0189)}

The SEN0189 sensor is a sensor that can be used to measure the turbidity level of water in NTU units. The test is performed using turbidity calibration solution. The solution used is the solutions of 1 NTU, 100 NTU, and 500 NTU. The value is taken 30 times and the results are averaged. Table 3 shows the results of turbidity sensor testing.

Table 3 Turbidity Sensor Testing (SEN0189)

\begin{tabular}{|l|l|l|l|l|l|}
\hline Testing & $\begin{array}{l}\text { Calibration } \\
\text { Fluid (NTU) }\end{array}$ & $\begin{array}{l}\text { Sensor } \\
\text { SEN0189 } \\
\text { (NTU) }\end{array}$ & $\begin{array}{l}\text { Err } \\
\text { or } \\
(\%)\end{array}$ & $\begin{array}{l}\text { Fault } \\
\text { Tolerance }\end{array}$ & $\begin{array}{l}\text { Accur } \\
\text { acy } \\
(\%)\end{array}$ \\
\hline 1 & 1 & 1 & 0 & 0 & 100 \\
\hline 2 & 100 & 93.42 & 6.58 & 6.58 & 93.42 \\
\hline 3 & 500 & 458.41 & 8.32 & 41.59 & 91.68 \\
\hline Average & & & 4.96 & 16.06 & 95.03 \\
\hline
\end{tabular}

Based on the experiment listed in Table 3, the average accuracy measurement of the turbidity sensor reaches $95.03 \%$ of calibration solution.

\section{E. E-mail Alert}

The system provides warning to the factory owner via email registered in the system. When the system receives data and it is considered to be "bad", an e-mail is sent to the owner informing such a critical data/situation. The status of "bad" is considered when the temperature sensor readings are above $38^{\circ} \mathrm{C}$, or the $\mathrm{pH}$ sensor is beyond the value of $3-9$, or the turbidity value is above 50 . The alert information can be seen in Fig. 8. 


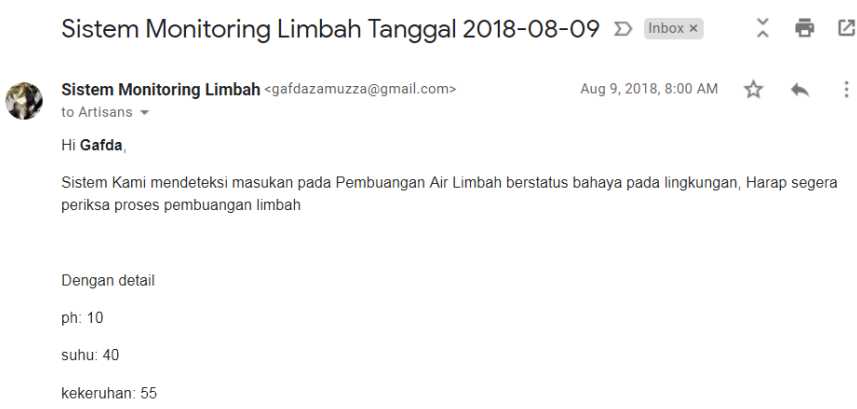

Fig. 8. Alert Email

Table 4 Email alert testing

\begin{tabular}{|l|l|l|l|l|l|}
\hline $\begin{array}{l}\text { Testin } \\
\text { g }\end{array}$ & $\begin{array}{l}\text { Tempera } \\
\text { ture } \\
\text { Sensor } \\
\left({ }^{\circ} \mathbf{C}\right)\end{array}$ & pH Sensor & $\begin{array}{l}\text { Sensor } \\
\text { SEN0189 } \\
\text { (NTU) }\end{array}$ & $\begin{array}{l}\text { Status } \\
\text { (good/ba } \\
\mathbf{d})\end{array}$ & $\begin{array}{l}\text { Email } \\
\text { Send } \\
(\mathbf{Y} / \mathbf{N})\end{array}$ \\
\hline 1 & 40 & 6 & 47 & bad & $\mathrm{Y}$ \\
\hline 2 & 32 & 11 & 46 & bad & $\mathrm{Y}$ \\
\hline 3 & 31 & 6 & 54 & bad & $\mathrm{Y}$ \\
\hline 4 & 40 & 10 & 58 & bad & $\mathrm{Y}$ \\
\hline 5 & 45 & 2 & 55 & bad & $\mathrm{Y}$ \\
\hline 6 & 31 & 8 & 46 & good & $\mathrm{N}$ \\
\hline 7 & 31 & 7 & 47 & good & $\mathrm{N}$ \\
\hline 8 & 33 & 7 & 47 & good & $\mathrm{N}$ \\
\hline 9 & 32 & 7 & 46 & good & $\mathrm{N}$ \\
\hline 10 & 32 & 8 & 46 & good & $\mathrm{N}$ \\
\hline
\end{tabular}

Table 4 shows the testing of email alerts. The system sends an e-mail alert to all "bad" status of data.

\section{CONCLUSION}

The system can accurately display waste water data from factories. Geographic Information System shows the location of the waste water plant as well as the existing condition of waste water. The accuracy of the sensor is $93.42 \%$ for turbidity. The system works well sending alerts to the factory owner when the waste water conditions exceed thresholds set.

\section{REFERENCES}

[1] S. Ghosha, A. J. Goswamia, G. K. Ghoshb, and P. Pramanika, "Quantifying the relative role of phytase and phosphatase enzymes in phosphorus mineralization during vermicomposting of fibrous tea factory waste," Ecological Engineering.,vol 116, pp. 97-103. 2018.

[2] Y. Chen, and D. Han, "Water Quality Monitoring in Smart City: A Pilot Project," Aoutomation in Construction,vol 89, pp. 307-3016. 2018.

[3] Y. Song, J.Lin, M.Tang and S. Dong, "An Internet of Energy Things Based on Wireless LPWAN," Engineering, vol 3, pp. 460-466. 2017.
[4] Y. Song, J. Lin, M. Tang, and S. Dong, "An Internet of Energy Things Based on Wireless LPWAN," Engineering., vol 3, pp. 460-466. 2017.

[5] S, Madakam, R. Ramaswamy, and S. Tripathi, "Internet of things (IoT): A literature review," Journal of Computer and Communications., vol 3, pp. 164-173. 2015.

[6] A. Colacovic, and M. Hazialic, "Internet of Things (IoT): A Review of Enabling Technologies, Challenges, and Open Research Issues," Computer Networks., 2018.

[7] X. Qiu, H. Luo, G. Xu, R. Zhong, \& G. Q. Huang. "Physical assets and service sharing for IoT-enabled supply hub in industrial park (SHIP)". International Journal of Production Economics, 159, pp. 4-15. 2015.

[8] R. S. Sinha, Y. A. Wei, and S. H. Hwang, "A survey on LPWA technology: LoRa and NB-IoT". ICT Express., vol 3 pp. 14-21. 2017.

[9] R. Jedermanna, M. Borysova, N. Hartgenbuscha, S. Jaegerb, M. Sellwigc, and W. Lang, "Testing Lora for food applications - Example application for airflow measurements inside cooled warehouses with apples," Procedia Manufacturing., vol. 24, pp. 284-289. 2018.

[10] A. J. Wixted, P. Kinnaird, H. Larijani, A. Tait, A. Ahmadinia, and N. Strachan, "Evaluation of LoRa and LoRaWAN for wireless sensor networks," IEEE SENSORS, pp. 1-3. 2016.

[11]T. Petric, M. Goessens, L. Nuaymi, A. Pelov, and L. Toutain, "Measurements, Performance and Analysis of LoRa FABIAN, a realworld implementation of LPWAN," Jun. 2016,

[12] D. Magrin, M. Centenaro, and L. Vangelista, "Performance Evaluation of LoRa Networks in a Smart City Scenario," IEEE ICC SAC Symposium Internet of Things Track. 2017.

[13] Crosier, Scott., “ArcGIS 9: Geocoding in ArcGIS," ESRI Publiser., Redland, New York, 2004.

[14] R. Nourjou, and M. Hashemipour, "Smart Energy Utilities based on Real-Time GIS Web Services and Internet of Things," Procedia Computer Science, vol. 110, pp. 8-15. 2017. 